PROBLEMS

OF MANAGEMENT IN THE $21^{\text {st }}$ CENTURY

Vol. 14, No. 1, 2019

\title{
MANAGING SUSTAINABILITY: THE ROLE OF MULTINATIONAL CORPORATIONS IN THE GLOBAL SOUTH
}

\author{
Marc Jacquinet \\ Open University of Lisbon, Portugal \\ E-mail: mjacquinet@gmail.com \\ Luca Bussotti \\ Federal University of Pernambuco, Brazil \\ CEI-ISCTE IUL Lisbon, Portugal \\ E-mail: Lbiau@iscte-iul.pt
}

\begin{abstract}
Multinational corporations and international business practices as well as international investment are considered important elements for the diffusion of new modes of production, namely through a flow of cleaner production and new management practices such as corporate social responsibility (CSR). This view is lacking consistency and is not buttressed on strong empirical evidence. The positive driver of environmental sustainability is probably not international business and trade but strong and good institutions. The focus here is on four limitations: the context of the private firms and corporations, the workings of complex organizations, the technology and the right institutions that buttress the global, national and local contexts, taking as concrete examples some specific cases from the Global South, as Mozambique. The article concludes that these aspects have to be considered and contrasted to the technological and management solutions for sustainability.
\end{abstract}

Keywords: corporate social responsibility, local communities, technology institutions.

\section{Introduction}

In the recent decades, corporations have been asked to contribute positively to such issues as global poverty, human rights, climate change, and, more recently still, global sustainable goals of the United Nations (UN 2015, 2016). This move is not innocent and relates to corporate scandals, such as Enron and many ensuing more, and the recurrent problems, globally connected to corporate activities and the downgrading of social and labour rights and conditions. The rise of corporate irresponsibility (environmental pollution, sweatshop, transfer of value chain activities to places where social constraints and labour conditions are much lower) has increased, in the public and activists eyes, the necessity of taking corporate responsibilities more seriously (Delmas-Marty and Supiot, 2015; Dardo and Laval, 2019).

\section{Problem of Research}

The fixes of social ailments and environmental degradation are presented in terms of techniques or technological solutions, and in the business world, three of these are CSR, innovation (especially under the heading of technological innovation with the last wave of digital technology), and business practices and management tools (benchmarking, lean production, 
knowledge management, etc.). In one way or the other, these techniques are deemed to contribute not only positively, but also significantly and necessarily, to sustainable development and to the UN sustainable development goals (SDGs). The proposition that the correlation is positive between reduction of pollution, poverty and other sustainable development goals with tools such as technological innovation and corporate social responsibility is not guaranteed; it can even be negative (See the Jevons Paradox, in Alcott, 2005; Ruyttinger et al., 2015).

It is obviously relevant, however, that the expected positive impacts are not sufficient within the current innovation paradigm (Godin, 2017) and the way CSR and other management tools are used and integrated with regard to the broader context of the environmental and social problems at hand in the developing world.

Our analysis focuses on four limitations of the optimist view of the national and international corporations (multinationals and beyond) and technological innovations as positive drivers for change (Sikdar et al., 2017) in terms of reducing poverty, reversing adverse effects on climate change and enhancing the life of local communities. In the optimist view, first, the context, in which the corporations are acting, is not fully considered in its relevant breadth and depth, in terms of economic, social and environmental impacts. Second, the very dynamics of the corporations is not properly assessed in all its complexity (internal and external). Third, the technology is insufficiently related to users and the population impacted or that is avoided on purpose (Prud'homme et al, 2018). Finally, the institutions are not sufficiently analysed, beyond some legal and formal considerations. The political dimension has to be much more thoroughly assessed.

It is important to insist that the question of the contribution of corporations for sustainability is taken here in a thorough and radical sense, going beyond social inequality, poverty and limiting their impact on the environment, directly and indirectly.

\section{Research Focus}

The present analysis focuses on multinationals rather than the whole categories of firms; however the general points made here are extendible to the various strands of firms and companies. Even some NGOs, with a commercial culture, could be included, without much adaptation. This is so because the management culture is overwhelmingly pervasive in all spheres of organizations' action, namely through the vast training programs of business schools.

The context for technological change (and transfer) as well as for the action of multinational corporations is often either ignored or much neglected (Amesse and Cohendet, 2001; Archibugi and Pietrobelli, 2003; Sikdar et al., 2017); in the latter case, it is reduced to some familiar notions of cultural, legal, economic, business and social elements without much content (such as the publications of the World Bank on doing business abroad). This is typical of private consulting firms that publish quantitative data without much method, transparency and relevance.

The importance of context is not just relevant to all social sciences, it is important for social intervention, business decisions and political initiatives. In ethics too, context matters (Hunyadi 2015), practical reason and moral principles are subject to the reflexive power of agents (social actors, decision makers, CEOs and workers, inter alia). Context might provoke a bypass of a formal or rational procedure as well impose a deeper reflexion on a subject matter, especially when dilemmas are present and the consequences are either risky or subject to public scrutiny or of special concern for the people involved (Bussotti, 2014).

The notion of context adopted here is described as relevant to the task of research and description of the problem at hand. To do so, it is necessary to combine theoretical sophistication, methodological rigor, the historical dimension and some reasoned creativity.

\author{
PROBLEMS \\ OF MANAGEMENT \\ IN THE $21^{\text {st }}$ CENTURY \\ Vol. 14, No. 1, 2019 \\ 43
}


PROBLEMS

OF MANAGEMENT

IN THE $21^{\text {st }}$ CENTURY

Vol. 14, No. 1, 2019

Historically, the issues of innovation and technological transfer, namely from the North to the South - and now also from South to South - were and are still neglecting the dimensions of culture, social value, attitudes of actors, local knowledge and practices. A great proportion of economic development and technological transfer initiatives were failures on these counts: lacking attention to the relevant context.

Technological innovation, after the invention and transfer, has still to be understood, adapted, adopted and used in daily life. The factors behind the failures are numerous; some are highlighted in the next section on the technology dimension, others are related to the economic, social and cultural context.

It is especially salient to highlight the local and regional contexts that increase the risk of CSR initiatives and technology transfers. If there is already a lack of knowledge of many developing countries, in terms of CSR practices (Visser, 2008, 2010; Visser \& Tolhurst, 2017), such as those on the African continent, often limited to South Africa and Nigeria (Tallio 2017); at the local level, the flaws of the generalizations are even starker. It is relevant for successful technology transfer to have some input from the local knowledge of actors, workers and communities (Pietrobelli \& Rabellotti, 2011). For CSR projects, the participation of local communities is also very crucial for their success (Scoones et al., 2018) and to avoid qui-pro-quos and false expectations, not to mention injustice and non respect of basic rights. In both types of business policies, the local knowledge can be a significant factor for reducing operating costs, transaction costs, and avoiding unnecessary conflicts.

In the present study of technological change and the contribution of corporations to sustainability, the environment in which business decisions are made matter not only for the success of the organizations, but also for the workers, citizens, and local communities. The environment for business has to include not just the economic, social and political dimensions, but also the natural and ecological systems that humanity is part of. That part is often lacking for multinational corporations investing in natural resources extraction such as mining.

Finally, the whole context allows us to assess the complexity of the problem at hand related to social equity, environmental protection and human flourishing (Sayer, 2011). Cumulative to the context, the proper internal workings of corporations are worth an accurate analysis as it is discussed in the next section.

\section{Research Methodology}

The research presented here was carried out using a qualitative approach, based on two main elements: firstly, on the analysis of the current literature in relation to the issue here approached; secondly, on a case-study from a list of 31 severely off track countries (SOTC), namely Mozambique, in order to show what is the role of multinational corporations in the development of these countries at the moment, and how it could be in the case they adopted a different practice of CSR.

In particular, the review of the literature consisted in analysing: (1) the corporate social responsibility, technological change and development (Daugareilh 2009a, 2009b); (2) the severely off-track countries (Gertz \& Kharas 2018) and states of fragility (OECD 2018). The case study has been centred on Mozambique, belonging to the above-mentioned list of the 31 SOTC.

The qualitative dimension of the research has to be highlighted because the focus on CSR, technology and institutions is not much studied across countries in the global south. This is a pioneering work that can be promising in the future for better understanding the interplay of context, institutions, technology, CSR practices and corporate strategies.

For the review of the literature on CSR, the focus was mainly on practices of multinational in developing countries where the exploitation of natural resources and land is very important and triggers questions about the role and feasibility of attaining sustainable develop- 
ment goals while depleting natural capital. This review is complemented by a critical analysis of technological change and the promises of innovation (see Kranzberg's principles below). Both allow us to consider in a second phase the relevance of national and local contexts, or country-specific characteristics, based on the analysis of severely off-track countries and the fragile states (see States of fragility below and SOTC).

Finally, the focus on Mozambique is justified for several reasons. First, it is an exemplary case-study, showing a lot of investments, donors' projects, new forms of management of land, and all that on an unseen scale and scope, combining North-South and South-South endeavours. Second, the social and environmental problems in Mozambique are acute and can be compared to most other countries in the OECD (2018) analysis and the research by Gertz and Kharas (2018).

\section{Research Results}

The main result of our research consists in the proposal to deconstruct some basic concepts related to the aging of multinational corporations and to CSR. So, in the next section of the discussion of the results we firstly, present a conception of the corporation as a complex entity (Perrow 1986; Jacquinet, \& Caetano, 2010), and, second, we consider critically the notion of shareholder value, that is the value of the firm as the result of the aggregation of the price of the different shares that make up their total capital (Stout, 2012) and considering its technological dimension and the role of institutions. Finally, we present a case-study of a country (Mozambique) belonging to the group of SOTC, as an empirical evidence of our results.

\section{Discussion}

\section{Shareholder Values}

The notion of shareholder value is important in the present analysis for several reasons. One it is the dominant view, still now, in business schools, economic faculties, financial markets and the banking system for assessing what worth is a corporation, and how can be measured the contribution of corporations for the well-being of nations, states, individuals and social groups. Another reason is analytical and methodological: the motivations and the foundation of business decisions, like investment projects, are a function of the shareholder value or the consequence of any decision on the price of the share and the market value of the firm. It acts as a criterion for taking business decisions, and this not just for considering investment in new green technologies versus environment unfriendly alternatives, but also for taking a view on what could be the next CSR project for any corporation X. It usually focuses on short-term information, so there is quite volatility of the underlying measures, leading to frequent chaotic and sub-optimal decisions.

After the financial crisis that blasted in 2007, it is crucial to discuss how corporations work, from their incorporation or legal constitution to their internal decisions and passing through the workings of shareholder influence and board meetings.

Important and difficult questions to discuss are those of power, pollution, (dis-)respect of human rights, non disclosure of relevant information, among others, and they are related to and influenced by the daily use of criteria based on shareholder value. In the short-term, the firms have to respond to financial markets scrutiny.

Shareholder value is often presented as a theory, it is in fact a combination of different theories coming from economics (finance and microeconomics) and is referred to, more appropriately by legal scholars (Stout, 2012, 2013) as a doctrine or even, form a legal point of view, a myth (Stout, 2012). It is moreover a legal fiction that grew so unilaterally away from other legal 
PROBLEMS

OF MANAGEMENT

IN THE $21^{\text {st }}$ CENTURY Vol. 14 , No. 1,2019

concepts that it lost ground from the productive, labour, social and environmental realities (Supiot, 2015; Delmas-Marty \& Supiot, 2015). It can also be considered as an economic doctrine from the history of economic thought and the heterodox literatures in economics. This a rather dominant conception of how corporations should be valued and their responsibility be defined. This doctrine goes very far indeed. The irony with the current financial crisis that took a load on the economic theory behind the shareholder value view of the firm is that this very theory is also one of the main reasons for the very collapse of the economy.

The shareholder value has influenced law, market mechanisms, financial markets and corporate governance as well as the legal scholars, economists (namely the law and economics movement and, agent-principal theory and financial economics), management and accounting scholars, not to mention consultants. In other words, economic actors use the doctrine daily in financial markets, accounting and equity management and this doctrine dominates not just the academic literatures, but also business schools and, more critically, management and legal practice.

This concept of shareholder value - above the interest of stakeholders, workers and citizens- led and leads to short termism in management decisions (Moore and Walker-Arnott, 2014), at all levels, implying a high risk for reaching bad compromises for the ecological systems, society and poor citizens that are not integrated in the processes. This is bad news for reaching deals that care for the environment and eradicate social problems that need long-term solutions. In other words, the principle of shareholder value undermines the approximation to most of the sustainable development goals.

\section{The Technological Dimension}

The other aspect of the present contribution has to do with the issue of innovation, technological change that substitutes inefficient technologies by more economical ones in terms of energy consumption and environmental impact. It is also a reflection on the role of technology in the productive systems as well as in society. There is here also an inherent ethical dimension to the question of technology and its varied impacts (Werhane, 1998, 2015).

Above all, it is important to note that technological innovation and the use of cleaner technologies can go in the right direction for ecological conservation. This means that it can reduce current impact of capitalist production activities, in absolute terms, and can mitigate the use of limited resources (fossil fuels, non-renewable natural resources, and rare earth, for example). This however is not enough, given the expansion of capitalist modes of production across the globe and the diffusion of supply chains across countries that make the tracking of ecological impact much more difficult and less transparent.

Innovation and technological change are considered - no matter what happens - as having a positive impact, this is at least the dominant or received wisdom in management and engineering related to sustainability discourse and corporate social responsibility. To discuss thoroughly this topic, Kranzberg's classical characterization of technological history (known metaphorically in the literature as Kranzberg's laws) is used as a yardstick (Kranzberg, 1986). It is based on six principles that are discussed briefly before concluding on the necessity to move beyond the simple technological fix of the environmental problems and the issue of global warming and its global impact on ecosystems and human societies.

The first principle is not to conceive technology as either good or bad or even neutral, but rather it can be both, it depends much on where and how it is used. Because of the context, technology introduces innovations that are neither good nor bad and they are not neutral either, which is much in sharp contrast to tech optimists and the corporations that defend a successful innovation, namely in terms of protection of patents or trademarks. Often innovations can be both, good and bad, like the use of DDT in India against malaria and its contamination of food 
as well as the pollution that resulted thereof for the environment, for many countries where it was a common recourse for pest control.

The second principle is that technological change is the mother of necessity, that is a change in one technique implies necessary change in other areas. In developing countries, the adoption of digital and mobile technologies by transversal corporations such as banks or insurance companies, or transport and water supply networks, means that clients, other businesses in the supply chain have to adapt their technology and interfaces.

Third, as conceived by Thomas Hughes, technologies organize themselves into "systems" or come into "packages" (Kranzberg's, 1986) and are characterized by interrelatedness between its components and embedded in more or less complex hierarchical or network structures. This third property makes technology transfer difficult not just to developing countries but to different cultural areas of the world and even in advanced economies with dissimilar sectoral structures. This is one of the factors of the failure of technological transfer between countries and corporations.

Furthermore, technology history is, according to Kranzberg and other historians, the most important part of history. This can be interpreted as the central cumulated technological system having taken place in our daily life, namely at the professional and domestic levels.

Finally, as the fifth principle, technological innovation is a very human activity and this means that people have to make use, organize, repair, remix and transform technological systems and any technology that is part of it. This last principle is important not just to discuss the recurrent debate on technological determinism (as it is the case for the fourth principle too) but also for considering the use of technology and innovation by corporations and their impact on jobs, society and the ecological system.

From all those principles, the technological question of sustainability is much more complex than usually presented. This does not mean that innovation for sustainability is not important or not that important. It is crucial, and it must be associated with other measures such as stronger and compulsory rules and targets for corporate social responsibility policy. Consequently, the technological dimensions of sustainability are not just the promotion of green technologies that reduce ecological footprint. They have to include the user, and in health and ecological systems, the patient and the local communities that have a better knowledge of the recent history of either their health and their normal behaviour or state.

Technologies, as noted earlier, are socially embedded (the culture or context) and this neglect can be jeopardizing the accomplishment of primary goals on other counts, namely when considering the physical dimensions and how technologies are used and perceived. This conclusion is not only relevant for the issue of technology transfer (Amesse \& Cohendet, 2001) but as well as for new management tools or CSR policies (Sillitoe, 1988).

Technology transfer to be successful needs not just an understanding of how a specific technique works but also how it will be interpreted and used in the setting of its destination to concrete users (Amesse \& Cohendet, 2001), namely in a developing country. In other words, the importance of the setting or context of implementation and use is important. Another aspect is often neglected. What were the objectives of the technological transfer and were they rightly characterized from the planning stage to the investment and implementation phases? Very often, the decisions are taken and the investment is made before the pertinent local knowledge is explicitly revealed and the decision makers have come to realize that it is too late to change the technological project. They then follow a path on the wrong track because the objectives or needs were not correctly assessed. These issues and others related to technology transfer are already well-known in the literature (Kedia \& Bhagat, 1988).

CSR and technological innovations are both technological fixes to economic and management problems, and these matter beyond their restricted spheres and encompass society and the natural environment. There is however one danger in technology fixes and management 
PROBLEMS

OF MANAGEMENT

IN THE $21^{\text {st }}$ CENTURY Vol. 14 , No. 1,2019

techniques, they are prey of the ideology of "no-limits" (Supiot, 2015) which is typical of business schools and management literatures - both academically and professionally speaking. This ideology of a capacity without limits for corporations and humans to solve any problem can be characterized as follows: "When a pervasive scientism converges with the Western belief in progress it produces an ideology of the unlimited which makes itself felt in every sphere of human life. In the field of technology it is expressed by an unshakeable faith in future discoveries that will be able to counter the threats to our planet which our technological and economic hubris keeps multiplying" (Supiot, 2005, p. 78).

\section{The Co-Presence of Difference and the Role of Diverse Institutions}

The question here is not just the existence of the right market institutions or those related to job competences, but also the diversity of the institutions and the importance of differences between countries and regions. All these institutional aspects matter for technological innovation, technological transfer, and corporate social responsibility.

Before discussing the issue of institutions for sustainable development or corporations and technological change, it is worth pointing out what is meant by institutions. According to Hodgson, Institutions can be defined "as systems of established and prevalent social rules that structure social interactions" (Hodgson, 2006, p. 2). This makes clear that the notion is broader than formal organizations such as central banks, the state, and other organizations. It encompasses legal and informal rules that are crucial for the working of a specific society and are important for successful development of the attainment of specific goals in public policies.

In the context of developing countries, and very often in those with important renewable and non-renewable natural resources, with typical trade-offs between the necessities of local communities and the interests of big corporations and multinationals, a central institution is the state, its role, how it deals with national elites and citizens and traditional settlements close to the critical sites of exploitation of the very coveted resources. Along with the rule of law, human rights, and other features, it is important here to insist on the proper role and functioning of the state is crucial, whether it can be deemed strong, weak or failed.

Accordingly, one institutional aspect relevant for discussing the impact of technological change, innovation, CSR and public policies, in developing countries, is the characterization of the state and how does it interact with multinationals, the international concert of nations, national elites and local communities. One important class of cases is the weak and failed state. The literature on a weak or failed state considers the characterization of any state or country along a continuum from strong states (mainly North America, Europe and Japan) to failed (and collapsed) states, with the weak state as an intermediary type (Migdal, 1988, 2010; Rotberg, 2005, 2010).

Without entering in the controversy, weak states can be considered as states experiencing serious problems of sovereignty domestically (to simplify) that cannot protect local communities, citizens with regard to elites, big corporations and other threats. According to Tyagi (2012, p. 1) the notion of a weak state is "generally used to define a state that is weak in its core functions of providing security to its citizens (security gap), providing basic services to its citizens (capacity gap), and having legitimacy among its people (legitimacy gap).” This definition can be applied conveniently to countries such as Angola, Mozambique, Namibia, South Africa, and several Latin American countries, like Chile or Bolivia, where international mining companies have impacted negatively local environments without much opposition from the domestic state. To illustrate these former points, it is important to discuss a typical and relevant case like Mozambique. 


\section{The Case of Mozambique}

In our analysis, the focus is on a country that is among those with the greatest challenges for SDGs and climate change impact: Mozambique. It is part of a list of 31 severely off track countries (SOTC), composed basically from African and Asian continents (Gertz \& Karhas, 2018).

According to Gertz and Karhas, $80 \%$ of people living in extreme poverty will live in these 31 countries, the severely off track countries that combine several and serious difficulties for attaining sustainable development goals and resisting to the impacts of global warming (Gertz \& Kharas, 2018).

This is one of the institutional features, that can be related to multinationals, elites and the extent to which the rights of the communities and the integrity of their environment and of the ecological systems are not guaranteed. In the case of Mozambique, multinationals reach agreement with government officials without public scrutiny. In truth, a public, community meeting is mandatory, according to the Land Law 19/97 and to its Rule Book (Decree 66/98), but in general these meetings are conducted to obtain the consensus of local communities, without giving them proper information. So, great investments in land in Mozambique - particularly important starting from 2007-2008 - has been defending the interests of multinationals in alliance with the national elites and in detriment of the local communities. Such a situation can be shown by the (open pit) coal mines in Tete, eucalyptus plantations by Portucel in Manica and Zambezia, and sugar plantation in Manhiça. In all these three cases (not to speak of the mega-project Pro-Savana, in the North of the country), local populations have been the victims of great investments carried out by multinationals, and sustained by local authorities. In Tete, a long and conflicted process of resettlement expulsed local communities without giving them an adequate alternative (Lillywhite, Kemp, \& Sturman, 2015; Pedro, 2015). In Manica and Zambezia, local communities have been able to stop or to force to renegotiate the original investment of the Portuguese company Portucel (controlled by The Navigator Company). The investment consisted in occupying about half a million hectares, forcing local peasants to become dependent workers of Portucel, leaving their food cultures (EPN, ADECRU, Quercus, ARA \& KKM, 2015). Finally, in the South of Mozambique (in Manhiça, Maputo's Province), the sugar cane production in the hand of corporations (especially Maragra Açúcar, S.A.) required peasants to adopt monoculture (cane) versus traditional cultures and get rid of local food production which obliges them to buy food at market prices (O'Laughlin \& Ibraimo, 2013).

It is important to make the following considerations. First, in other words, the weak states promote or give leeway to extractive political and economic institutions while strong states facilitate the thriving of inclusive political and economic institutions. The weak state does not guarantee a level playing field for individuals and communities. This is a serious hindrance for implementing decent and ambitious CSR policies or to foster technological innovation for countering climate change.

Second, the negative effects of global warming are considered to affect not just the Southern countries but above all much more the poor communities in the global south, be these rural areas, agricultural families, fishing villages and urban or rural poor working in factories or big projects. At the present moment to talk of resilience is inadequate because the current situation is one that fosters exacerbation of inequalities, poverty and vulnerability on various counts. People and resources are exhausted even before the coming global warming challenges and are not getting prepared for the risks of the future.

Third, CSR practices and big investment projects are far from answering the current challenges and often do not sit easily with the question of rights and the rule of law (Bussotti, 2014, Dare, 2018; Uduji \& Okolo-Obasi, 2017). On the one hand, very often, CSR projects are very limited contributions to problems such as health, education and poverty, which are 
PROBLEMS

OF MANAGEMENT

IN THE $21^{\text {st }}$ CENTURY Vol. 14 , No. 1, 2019

state obligations and people's rights. On the other hand, many big investment projects do create pollution problems, change the way of life, create higher dependency on markets, trigger lower capacity of resilience for local communities and exacerbate the widespread exhaustion of natural resources.

Finally, this exhaustion of natural resources, especially when they are not renewable or if renewable but causing high costs such as monoculture, is also an issue or the coming generations in these countries that concentrate acute and complex problems. Consequently, no discussion or vision of the future is emerging that tackle the current social and environmental ailments.

\section{Conclusions}

As a first and crucial conclusion, the different elements - the context, the complex organizations (and the shareholder theory), the technological dimension and the institutions - have to be considered simultaneously for a thorough study of the challenges for sustainability that CSR, corporations and innovations could tackle.

Another issue that has to be underlined is the current and widespread lack of public policies in developing countries, focusing on relevant targets for the conservation of ecosystems and nature. This is obvious for scholars but not so for shareholders and investors, and the transformations have to foster long-term investment over short-termism in management and investment (Dallas, 2011; Desai Rittenburg, 1997; Moore \& Walker-Arnott, 2014).

Beyond the importance of context, there is a necessity to integrate the limits of technology and tackle the behaviour and negative impacts of corporations and the consumerism of today's modernity. There is a need to go over the contradiction between genuine sustainability and corporate goals and shareholder value primacy. In this respect the emphasis has to be on institutions such as the law, international conventions, compacts and regulation. This is a thorny issue in developing countries, but it has to be tackled with a better framework of analysis, policy making and assessment.

Finally, the analysis of countries such as Mozambique, among others, shows that CSR and technological change are serious enough to be discussed more broadly, with a wider group of stakeholders, beyond central government representatives and managers of multinationals. The communities have a relevant knowledge of local problems and their integration can make the investment more respective of human rights, environmental conservation and contention of poverty. The results about Mozambique can be compared to other developing countries such as Angola and Congo (RDC), and many other African countries of different scales.

\section{References}

Alcott, B. (2005) “Jevons' paradox”. Ecological Economics, 54(1), 9-21, https://doi.org/10.1016/j. ecolecon.2005.03.020

Amesse, F., \& Cohendet, P. (2001). Technology transfer revisited from the perspective of the knowledgebased economy. Research Policy, 30(9), 1459-1478. doi: https://doi.org/10.1016/S00487333(01)00162-7.

Archibugi, D., \& Pietrobelli, C. (2003). The globalisation of technology and its implications for developing countries. Technological Forecasting and Social Change, 70(9), 861-883. doi: 10.1016/s00401625(02)00409-2.

Bussotti, L. (2014). Environmental risk management and communication in an African context: The case of the Mozal bypass in Mozambique. Cadernos de Estudos Africanos, 28. Retrieved from: http:// journals.openedition.org/cea/1692. doi: 10.4000/cea.1692.

Dallas, L. L. (2011). Short-termism, the financial crisis, and corporate governance. Journal of Corporation Law, 37, 265. 
Dardot, P., Laval, C. (2019). Never ending nightmare: The neoliberal assault on democracy. London and New York: Verso.

Dare, J. (2018). Do actions speak louder than words? An exploratory study on CSR. Business and Society Review, 123(2), 303-339. doi:10.1111/basr.12143.

Daugareilh, I. (2008). Employee participation, ethics and corporate social responsibility. Transfer. European Review of Labour and Research, 14(1), 93-110. doi: 10.1177/102425890801400109.

Daugareilh, I. (2009a). La responsabilité sociale des entreprises, un projet européen en panne [The social responsibility of the companies, a failed European project]. Sociologie du Travail, 51(4), 499-517. doi: https://doi.org/10.1016/j.soctra.2009.09.004.

Daugareilh, I. (2009b) Responsabilidad social de las empresas transnacionales: análisis crítico y prospectiva jurídica [Social responsibility of the transnational companies: A critical analysis and a legal perspective]. Cuadernos de Relaciones Laborales, Norteamérica, 27 (1). 77-106. Retrieved from: http://revistas.ucm.es/index.php/CRLA/article/view/CRLA0909120077A.

Daugareilh, I. (2015) La responsabilité sociale des entreprises en quête d'opposabilité [The social responsibility of companies in search of opposability]. In : A. Supiot et M. Delmas Marty (Eds.). Prendre la responsabilité au sérieux (Take the responsibility seriously). Paris: Seuil, pp.183-199

Delmas-Marty, M., \& Supiot, A. (2015) Prendre la responsabilité au sérieux [Take the responsibility seriously]. Paris: Seuil.

Desai, A. B., \& Rittenburg, T. (1997). Global ethics: An integrative framework for MNEs. Journal of Business Ethics, 16, 791. Retrieved from: https://doi.org/10.1023/A:1017920610678.

Doane, D. (2005). The myth of CSR. Stanford Social Innovation Review, 3(3), 23-29.

Doshi, S., \& Ranganathan, M. (2018). Towards a critical geography of corruption and powerin late capitalism. Progress in Human Geography, 0(0), 0309132517753070. doi: 10.1177/0309132517753070.

EPN, ADECRU, Quercus, ARA, KKM (2015). Usurpação da Terra para Celulose [Landgrabbing for Cellulose]. Retrieved from: http://www.environmentalpaper.eu/wp-content/ uploads/2017/11/171117-Discussion-Document-Portucel-Report-2017-Portuguese.pdf.

Fu, X., Pietrobelli, C., \& Soete, L. (2011). The role of foreign technology and indigenous innovation in the emerging economies: Technological change and catching-up. World Development, 39(7), 1204-1212. doi : https://doi.org/10.1016/j.worlddev.2010.05.009.

Galbraith, J. K. (2008). The predator state: How conservatives abandoned the free market and why liberals should too. New York: Simon and Schuster.

Gertz, G., \& Kharas, H. (2018). Leave no country behind: Ending poverty in the toughest places. New York: Brookings Institution.

Godin, B. (2017). L'innovation sous tension: Histoire d'un concept [Innovation under pressure: History of a concept]. Québec: Presses de l'Université de Laval.

Ho, Y.-P., Ruan, Y., Hang, C.-C., \& Wong, P.-K. (2016). Technology upgrading of Small-and-Mediumsized Enterprises (SMEs) through a manpower secondment strategy - A mixed-methods study of Singapore's T-Up program. Technovation, 57-58, 21-29. doi: https://doi.org/10.1016/j. technovation.2016.07.001.

Hodgson, G. (2006). What are institutions? Journal of Economic Issues, 40(1), 1-25. Retrieved from http://www.jstor.org/stable/4228221.

Hunyadi, M. (2015). L'approche contextualiste en morale: Mise au point en dix points [The contextualized approach in ethic: Current situation in ten points]. Revue d'éthique et de théologie morale, 284(2), 39-52. doi: 10.3917/retm.284.0039.

Jacquinet, M., \& Caetano, J. C. R. (2010). Modélisation de la complexité [Modelization and complexity]. In: A.-J. Arnaud (Ed.), Dictionnaire de la globalisation: droit, science politique, sciences sociale [A Dictionnary of Globalization: Right, political science and social science] (pp. 76-77). Paris: Lextenso-LGDJ.

Kedia, B. L., \& Rabi, S. B. (1988). Cultural constraints on transfer of technology across nations: Implications for research in international and comparative management. Academy of Management Review, 13 (4), 559-571.

Khayyat, N. T., \& Lee, J.-D. (2015). A measure of technological capabilities for developing countries. Technological Forecasting and Social Change, 92, 210-223. doi: 10.1016/j.techfore.2014.09.003.

Kranzberg, M. (1986). Technology and History: "Kranzberg's Laws". Technology and Culture, 27(3), 544-560. doi: 10.2307/3105385. 
Marc JACQUINET, Luca BUSSOTTI. Managing sustainability: The role of multinational corporations in the global South

PROBLEMS

OF MANAGEMENT

IN THE $21^{\text {st }}$ CENTURY

Vol. 14, No. 1, 2019

Lillywhite, S., Kemp, D. \& Sturman, K. (2015). Mining, resettlements and lost livelihoods: Listening to the voices of resettled communities in Mualadzi, Mozambique. Action Research Report, Oxfam. Retrieved from: https://www.im4dc.org/wp-content/uploads/2015/05/Mozambique-FR-1psumappr.pdf.

Migdal, J. S. (1988). Strong societies and weak states: State-society relations and state capabilities in the Third World. Princeton: Princeton University Press.

Migdal, J. S. (2010). State in society: Studying how states and societies transform and constitute one another. Cambridge: Cambridge Univ. Press.

Moore, M. T., \& Walker-Arnott, E. (2014). A fresh look at stock market short-termism. Journal of Law and Society, 41(3), 416-445. doi: 10.1111/j.1467-6478.2014.00676.x.

Mulongo, G., \& Amod, Z. (2017). Participation in cross-national learning assessments and impact on capacity development: Programmes, practice, structures and teacher competency. Case study of Kenya, Tanzania and South Africa. Evaluation and Program Planning, 65, 94-105. doi: https:// doi.org/10.1016/j.evalprogplan.2017.07.003.

Odera, O., Scott, A., \& Gow, J. (2018). Community perceptions of Nigerian oil companies commitment to social and environmental concerns. Journal of Global Responsibility, 9(1), 73-95. Retrieved from: https://doi.org/10.1108/JGR-02-2017-0006.

OECD. (2018). States of Fragility 2018. Paris: OECD Publishing, https://doi.org/10.1787/9789264302075en.

O'Laughlin, B., \& Ibraimo, Y. (2013). A Expansão da Produção de Açúcar e o Bem-Estar dos Trabalhadores Agrícolas e Comunidades Rurais em Xinavane e Magude [The expansion of sugar production and the well-being of the agricultural workers and rural communities in Xinavane and Magude]. Cadernos do IESE. Maputo: IESE. Retrieved from: http:/www.iese.ac.mz/lib/ publication/cad_iese/CadernosIESE_12p.pdf.

Pedro, J. (2015). Forced resettlements: From impacts to opportunities - The case of Moatize Mine (Mozambique). In: Afonso, A. (Ed.). Informality and Urbanization an African Contexts: Analysing Economic and Social Impacts (pp. 69-85). Lisbon: CEI-ISCTE.

Perrow, C. (1986). Complex organizations: A critical perspective. New York: McGrawHill.

Petit, Y. (2012). La fragilité environnementale et territoriale [The territorial and environmental fragility]. Civitas Europa, 28(1), 79-98. doi: 10.3917/civit.028.0079.

Pietrobelli, C., \& Rabellotti, R. (2011). Global value chains meet innovation systems: Are there learning opportunities for developing countries? World Development, 39(7), 1261-1269. doi: 10.1016/j. worlddev.2010.05.013.

Prahalad, C. K. (2014). The fortune at the bottom of the pyramid: Eradicating poverty through profits. Upper Saddle River, N.J: Pearson Education.

Prud'homme, D., Von Zedtwitz, M., Thraen, J. J., \& Bader, M. (2018). Forced technology transfer" policies: Workings in China and strategic implications. Technological Forecasting and Social Change, 134, 150-168. doi: 10.1016/j.techfore.2018.05.022.

Rotberg, R. I. (2005). Failed states, collapsed states, weak states: Causes and indicators. In Robert I. Rotberg (Ed.), State failure and state weakness in a time of terror (pp. 1-25). Cambridge, Mass \& Washington, D.C.: World Peace Foundation \& Brookings Institution Press.

Rotberg, R. I. (2010). When states fail: Causes and consequences. Princeton: Princeton University Press.

Rüttinger, L., Smith, D. F., Stang, G., Tänzler, D., \& Vivekananda, J. (2015). A new climate for peace: Taking action on climate and fragility risks: An Independent Report Commissioned by the G7 Members. Berlin: Adelphi.

Sayer, A. (2011). Why things matter to people: Social science, values and ethical life. Cambridge: Cambridge University Press.

Scoones, I., Edelman, M., Borras Jr, S. M., Hall, R., Wolford, W., \& White, B. (2018). Emancipatory rural politics: Confronting authoritarian populism. The Journal of Peasant Studies, 45(1), 1-20. doi: 10 $.1080 / 03066150.2017 .1339693$.

Sikdar, S. K., Sengupta, D., \& Mukherjee, R., (2017). Measuring progress towards sustainability. A treatise for engineers. Heidelberg: Springer International Publishing.

Sillitoe, P. (1998). The development of indigenous knowledge: A new applied anthropology. Current Anthropology, 39(2), 223-252. 
Stout, L. (2012). The shareholder value myth: How putting shareholders first harms investors, corporations, and the public. San Francisco: Berrett-Koehler Publishers.

Stout, L. (2013). The toxic side effect of shareholder primacy. University of Pennsylvania Law Review, 161(7), 2003-2023. Retrieved from: http://www.jstor.org/stable/23527857.

Supiot, A. (2005). Homo juridicus: Essai sur la fonction anthropologique du Droit [Homo juridicus: Essay on the anthropological function]. Paris: Presses Universitaires de France.

Supiot, A. (2015). La gouvernance par les nombres [The governance by the numbers]. Paris: Institut d'Études Avancées de Nantes/Fayard.

Tallio, V. (2017). La responsabilité sociale des entreprises: modèle de santé publique ou régime de santé globale ? L'exemple des entreprises pétrolières en Angola [The social responsibility of the companies: A model of public health or a regimen of global health ?]. Sciences sociales et santé, 35(3), 81-104. doi: 10.1684/sss.20170305.

Tyagi, J. (2012). Weak states. In G. Ritzer (Ed.). The Wiley-Blackwell Encyclopedia of Globalization. New York: John Wiley \& Sons.

Uduji, J., \& Ikechukwu Okolo-Obasi, E. N. (2017). Multinational oil firms' CSR initiatives in Nigeria: The need of rural farmers in host communities. Journal of International Development, 29. doi: $10.1002 /$ jid.3243.

United Nations (UN) (2015) Transforming our World: The 2013 agenda for sustainable development. New York, NY: United Nations.

United Nations (UN) (2016). Sustainable Development Goals Report 2016. New York, NY: United Nations.

Visser, W. (2010) CSR 2.0 and the New DNA of Business. Journal of Business Systems, Governance and Ethics, 5(3), 7. Retrieved from: http://ssrn.com/abstract=1725159.

Visser, W. (2008). Corporate social responsibility in developing countries. In: A. Crane, D. Matten, A. McWilliams, J. Moon, \& Donald, S. Siegel (Eds.), The Oxford handbook of corporate social responsibility (pp. 473-499). Oxford: Oxford University Press.

Visser, W., \& Tolhurst, N. (2017). The world guide to CSR: A country-by-country analysis of corporate sustainability and responsibility. London: Routledge.

Werhane, P. H. (1998). Moral imagination and the search for ethical decision-making in management. Business Ethics Quarterly, 75-98. Retrieved from http://www.jstor.org/stable/41968764.

Werhane, P. H. (2015). Moral Imagination. In: Wiley Encyclopedia of Management (Ed. C. L. Cooper). doi:10.1002/9781118785317.weom020036.

Received: May 02, 2019

Accepted: June 25, 2019

\begin{tabular}{l} 
PROBLEMS \\
OF MANAGEMENT \\
IN THE 21 $1^{\text {st }}$ CENTURY \\
Vol. 14, No. 1, 2019 \\
\hline 53
\end{tabular}

(1) 